\title{
Analisis Penggunaan Filter Damped untuk Mereduksi Total Harmonic Distortion (THD) di Rumah Sakit Umum Daerah (RSUD) Klungkung
}

\author{
I Kadek Arya Wiguna ${ }^{1}$, I Wayan Rinas ${ }^{2}$, I Wayan Arta Wijaya ${ }^{3}$
}

\begin{abstract}
The operation of non-linear load are causing harmonic. The level of distortion or called Total Harmonic Distortion (THD) is high potential to degrade the quality of electrical energy is distributed. In this study was conducted measurement of the THD at each Sub Distribution Panel (SDP) in Klungkung Hospital. The results of the initial measurements indicate the highest $I_{\text {THD }}$ value contained in the SDP P.AC amounted to $45.73 \%$ and the lowest is $3.93 \%$ at SDP UGD. While the value of the initial measurement result $V_{\text {THD }}$ an average of 5.3\% . Referenced standard is IEEE Standard 519-2014, wherein $I_{\mathrm{THD}}$ standard limit is $8.0 \%$, and the standard limit of $\mathrm{V}_{\mathrm{THD}}$ is 8.0\%. THD value which passed the standard is analyzed and simulated in software ETAP with the addition of a damped filter to reduce the value of THD which passed the standard. Based on the simulation results after the addition of a damped filter, $\mathbf{I}_{\mathrm{THD}}$ value has decreased in each of the SDP. However, only a few SDP with ITHD in accordance with the standard. The decrease $\mathbf{I}_{\mathrm{THD}}$ highest is $10.63 \%$ at SDP P.AC, and the lowest is $2 \%$ at SDP IPSRS. $V_{\text {THD }}$ value at each SDP after the addition of a damped filter also decreased with an average decrease of $1.74 \%$.
\end{abstract}

Intisari- Pengoperasian beban non linier merupakan penyebab timbulnya harmonisa. Tingkat distorsi atau disebut Total Harmonic Distortion (THD) yang tinggi berpotensi menurunkan kualitas energi listrik yang disalurkan. Dalam penelitian ini dilakukan pengukuran THD pada tiap $S u b$ Distribution Panel (SDP) di RSUD Klungkung. Hasil pengukuran awal menunjukkan nilai THD $_{\text {I }}$ tertinggi terdapat pada SDP P.AC sebesar $45,73 \%$ dan terendah pada SDP UGD sebesar 3,93\%. Sedangkan nilai THDV hasil pengukuran awal rata-rata sebesar $5,3 \%$. Standar yang dijadikan acuan adalah IEEE Standard 519-2014, dimana batas standar $\mathrm{THD}_{\mathrm{I}}$ adalah $\mathbf{8 , 0 \%}$, dan batas standar THD adalah 8,0\%. Nilai THD yang melewati standar dianalisis dan disimulasikan pada perangkat lunak ETAP dengan penambahan Damped Filter untuk mereduksi nilai THD yang melewati standar. Berdasarkan hasil simulasi setelah penambahan Damped Filter, nilai THD $_{\mathrm{I}}$ mengalami penurunan di tiap-tiap SDP. Namun hanya beberapa SDP dengan kandungan THD $_{\text {I }}$ yang sesuai dengan standar. Penurunan THD $_{\mathrm{I}}$ tertinggi terdapat pada SDP P.AC sebesar 10,63\%, dan penurunan terendah terdapat pada SDP IPSRS sebesar $2 \%$. Nilai THD $_{\mathrm{V}}$ pada tiap-tiap SDP setelah penambahan Damped Filter juga

${ }^{1}$ Mahasiswa, Jurusan Teknik Elektro dan Komputer Fakultas Teknik Universitas Udayana, Br. Dinas Wates Tengah, Duda Timur, Selat, Karangasem 80862 INDONESIA (tlp: 085739083303; $e$ mail: dekarya94@gmail.com)

2, 3 Dosen, Jurusan Teknik Elektro dan Komputer Fakultas Teknik Universitas Udayana, Jln. Kampus Bukit Jimbaran 80361 INDONESIA (telp: 0361-703315; fax: 0361-4321; e-mail: 2rinas@unud.ac.id, ${ }^{3}$ artawijaya@unud.ac.id)

I Kadek Arya Wiguna: Analisis Penggunaan Filter Damped... mengalami penurunan dengan rata-rata penurunan sebesar $1.74 \%$.

Kata kunci : Beban non linier, Total Harmonic Distortion, Sub Distribution Panel, Damped Filter

\section{PENDAHULUAN}

Sistem distribusi memiliki peran penting dalam proses penyaluran energi listrik dari sumber PLN ke konsumen. Energi listrik yang disalurkan harus memiliki kualitas yang baik dan tanpa adanya gangguan. Kualitas daya listrik menjadi hal penting yang harus dijaga karena melayani banyak bebanbeban listrik yang menuntut kualitas daya listrik sebaik mungkin untuk kelancaran operasional suatu sistem. Terdapat beberapa faktor yang menimbulkan penurunan kualitas daya listrik, salah satunya adalah distorsi harmonisa [1].

Penggunaan beban-beban listrik dalam jumlah yang besar khususnya beban nonlinier merupakan penyebab timbulnya harmonisa. Saat ini permasalahan terkait dengan harmonisa menjadi hal yang perlu diwaspadai karena memberikan implikasi negatif terhadap sistem seiring dengan berkembangnya peralatan-peralatan listrik dengan beban nonlinier [2]. Salah satu contohnya yaitu sarana publik seperti rumah sakit dengan pengoperasian peralatan-peralatan medis yang merupakan beban nonlinier. Beban nonlinier memiliki bentuk gelombang yang tidak sinusoidal karena telah terdistorsi oleh arus harmonisa. Distortion (kerusakan) gelombang sinusoidal yang mengalir pada sistem tenaga listrik disebut dengan Total Harmonic Distortion (THD) yang dinyatakan dalam satuan persen $(\%)$.

Tingkat THD yang tinggi pada saluran distribusi sehingga melebihi standar yang ditetapkan dapat dikategorikan sebagai gangguan sistem. Semakin besar THD-nya maka semakin besar rugi-rugi (losses) pada saluran sehingga efisiensinya akan semakin menurun [2]. Uupaya untuk meminimalisasi harmonisa pada sistem distribusi dapat dilakukan dengan penggunaan filter harmonik, dan salah satu jenis filter harmonik adalah damped filter yang dapat mengurangi harmonisa pada frekuensi yang tinggi. Damped filter tidak begitu sensitif terhadap perubahan temperatur, perubahan frekuensi, dan rugi-rugi kapasitor. Pada sejumlah kasus, penggunaan satu atau lebih damped filter dapat menjadi alternatif yang dapat diterima [3].

RSUD Klungkung memiliki 2 buah transformator distribusi 20kV/400V dengan kapasitas maksimum masingmasing sebesar 200kVA. Terdapat masing-masing 1 buah

p-ISSN:1693 - 2951; e-ISSN: 2503-2372

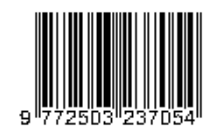


Main Distribution Panel (MDP) pada kedua transformator yang terpasang yang kemudian dibagi menjadi 18 Sub Distributin Panel (SDP). Dalam penelitian ini dilakukan pengukuran awal terhadap kandungan THD baik tegangan maupun arus saat beban puncak di tiap-tiap SDP yang terpasang di RSUD Klungkung. Hasil pengukuran yang diperoleh akan dibandingkan dengan standar IEEE 519 tahun 2014 yang dijadikan sebagai acuan analisis. Setelah dilakukan pengukuran awal diketahui bahwa rata-rata THD tegangan $\left(\mathrm{THD}_{\mathrm{V}}\right)$ pada transformator 1 dan transformator 2 yaitu sebesar $1.51 \%$, dan $1.78 \%$. Sedangkan rata-rata THD arus $\left(\mathrm{THD}_{\mathrm{I}}\right)$ pada transformator 1 dan transformator 2 yaitu sebesar $16.73 \%$, dan $13.04 \%$. Berdasarkan standar IEEE 519 tahun 2014 bahwa batasan $\mathrm{THD}_{\mathrm{V}}$ sistem dengan tegangan nominal dibawah $1 \mathrm{kV}$ yaitu sebesar $8 \%$. Sedangkan untuk menentukan batasan THD arus $\left(\mathrm{THD}_{\mathrm{I}}\right)$ disesuaikan dengan nilai rasio hubung singkat (SC ratio). Hasil perhitungan rasio hubung singkat yang telah dilakukan, rata-rata nilai SCratio-nya yaitu sebesar 25. Dengan SCratio sebesar 25 maka batasan $\mathrm{THD}_{\mathrm{I}}$ adalah sebesar $8 \%$. Sehingga diketahui bahwa $\mathrm{THD}_{\mathrm{V}}$ untuk Transformator 1 dan 2 masih memenuhi standar, sedangkan $\mathrm{THD}_{\mathrm{I}}$ pada transformator 1 maupun transformator 2 yang terukur tidak memenuhi standar.

Berdasarkan data awal yang diperoleh, maka tingginya tingkat $\mathrm{THD}_{\mathrm{I}}$ yang telah melewati standar akan direduksi dengan menggunakan damped filter sehingga dapat menurunkan nilai THD dari saluran distribusi di RSUD Klungkung.

\section{KUALITAS DAYA LISTRIK DAN TOTAL HARMONIC DISTORTION}

\section{A. Kualitas Daya Listrik}

Kualitas daya listrik menunjukkan setiap masalah daya listrik yang berbentuk penyimpangan tegangan, arus atau frekuensi yang mengakibatkan kegagalan ataupun kesalahan operasi pada peralatan-peralatan yang terjadi pada konsumen energi listrik. Daya adalah suatu nilai dari energi listrik yang dikirimkan dan didistribusikan, dimana besarnya daya listrik tersebut sebanding dengan perkalian besarnya tegangan dan arus listriknya. Satuan untuk daya listrik dinyatakan dalam Watt atau Horsepower (HP), dimana 1 HP setara dengan 746 Watt. [2]

\section{B. Total Harmonic Distrortion}

Harmonic Distortion atau distorsi harmonisa muncul karena pengoperasian beban non linier pada suatu sistem tenaga listrik. Beban non linier memiliki karakteristik arus yang tidak proporsional terhadap sumber, atau dengan kata lain gelombang tegangan yang berbentuk sinusoidal murni telah terdistorsi oleh arus harmonisa. [2]

Beban non linier pada umumnya merupakan komponen semikonduktor yang pada proses kerjanya bekerja sebagai saklar (switch) yang bekerja pada setiap setengah siklus gelombang atau beban yang membutuhkan arus listrik tidak tetap pada setiap periode waktunya. Proses kerjanya inilah yang akan menghasilkan gangguan atau distorsi arus maupun tegangan yang tidak sinusoidal.

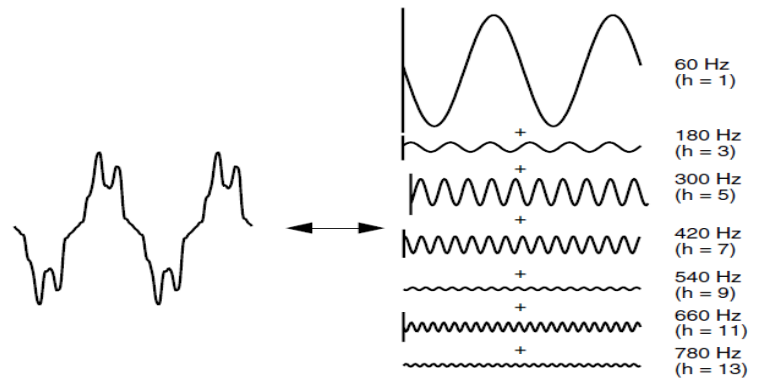

Gambar 1. Distorsi gelombang akibat harmonisa [2]

Harmonisa tegangan dapat mengakibatkan terjadinya peningkatan rugi besi (core-loss). Sedangkan harmonisa arus dapat mengakibatkan terjadinya peningkatan rugi-rugi tembaga. Secara keseluruhan rugi-rugi yang timbul akibat harmonisa merujuk pada terjadinya pemanasan berlebih (overheating) pada transformator.

Secara umum ada tiga pengaruh harmonik pada peralatan listrik, yaitu :

- Nilai RMS arus atau tegangan menjadi lebih besar. Nilai RMS yang lebih besar dapat mengakibatkan pemanasan yang lebih tinggi pada konduktor [4], [5], [6].

- Nilai puncak (peak value) tegangan dan arus lebih besar. Nilai puncak lebih besar dapat mengganggu kerja dari alat ukur, sehingga dapat terjadi kesalahan pada pembacaan[4], [5], [6].

- Menurunnya frekuensi pada sistem. Pada frekuensi tertentu, fenomena resonansi dapat terjadi yang dapat mengakibatkan arus meningkat [4], [5], [6].

\section{Standar Harmonisa pada Sistem Tenaga Listrik}

Standar harmonisa yang saat ini digunakan sebagai acuan adalah IEEE 519-2014. Standar THD $_{\mathrm{V}}$ yang diperbolehkan diatur sesuai dengan Point of Common Coupling (PCC) dimana setiap tingkatan tegangan memiliki standar yang berbeda-beda, begitu pula untuk standar $\mathrm{THD}_{\mathrm{I}}$ diatur sesuai PCC dan perhitungan rasio hubung singkatnya [7].

1) Standar $T_{H} D_{V}$ IEEE 519-2014: Standar $\mathrm{THD}_{\mathrm{V}}$ berdasarkan standar IEEE 519-2014 tentang nilai batas maksimum distorsi harmonik tegangan pada sistem dapat dilihat pada Tabel I.

TABEL I

VOLTAGE DISTORTION LIMITS [7]

\begin{tabular}{|c|c|c|}
\hline Bus Voltage (V) at PCC & $\begin{array}{c}\text { Individual } \\
\text { Harmonic (\%) }\end{array}$ & $\begin{array}{c}\text { Total Harmonic } \\
\text { Distortion (\%) }\end{array}$ \\
\hline $\mathrm{V} \leq 1 \mathrm{kV}$ & 5,0 & 8,0 \\
\hline $1 \mathrm{kV}<\mathrm{V}<69 \mathrm{kV}$ & 3,0 & 5,0 \\
\hline $69 \mathrm{kV}<\mathrm{V}<161 \mathrm{kV}$ & 1,5 & 2,5 \\
\hline $161 \mathrm{kV}<\mathrm{V}$ & 1,0 & 1,5 \\
\hline
\end{tabular}


Majalah Ilmiah Teknologi Elektro, Vol. 17, No. 2, Mei - Agustus 2018

DOI: https://doi.org/10.24843/MITE.2018.v17i02.P01

2) Standar $T H D_{I}$ IEEE 519-2014: Batas $\mathrm{THD}_{\mathrm{I}}$ yang direkomendasikan bagi pelanggan yang terhubung dengan sistem dimana tegangan berkisar antara $120 \mathrm{~V}$ sampai $169 \mathrm{kV}$ disesuaikan dengan Short Circuit Ratio (rasio hubung singkat) [7]. Short Circuit Ratio dapat dihitung dengan menggunakan persamaan sebagai berikut [2]:

$$
\text { Short Circuit Ratio }=\frac{I_{S C}}{I_{L}}
$$

$\mathrm{I}_{\mathrm{SC}}$ merupakan arus hubung singkat yang dapat ditentukan dengan persamaan berikut ini [2]:

$$
I_{S C}=\frac{S \times 100}{\% Z \times \sqrt{3} \times V}
$$

$\mathrm{I}_{\mathrm{L}}$ merupakan arus beban penuh yang dapat ditentukan dengan persamaan berikut ini [2]:

$$
I_{L}=\frac{S}{\sqrt{3} \times V}
$$

Dimana $\mathrm{S}$ adalah daya semu hasil pengukuran, $\mathrm{V}$ adalah tegangan hasil pengukuran, dan $\mathrm{Z}$ adalah impedansi saluran.

TABEL II

CURRENT DISTORTION LIMITS FOR SYSTEMS RATED 120 V THROUGH $69 \mathrm{KV}[7]$

\begin{tabular}{|c|c|c|c|c|c|c|}
\hline \multicolumn{7}{|c|}{ Maximum Harmonic Current Distortion } \\
\hline \multicolumn{7}{|c|}{ Individual Harmonic Order (odd harmonic) } \\
\hline $\mathbf{I}_{\mathbf{S C}} / \mathbf{I}_{\mathbf{L}}$ & $\begin{array}{c}\mathbf{3} \leq \mathbf{h} \\
\leq \mathbf{1 1}\end{array}$ & $\begin{array}{c}\mathbf{1 1} \leq \mathbf{h} \\
\mathbf{1 7}\end{array}$ & $\begin{array}{c}\mathbf{1 7} \leq \mathbf{h} \\
\mathbf{2 3}\end{array}$ & $\begin{array}{c}\mathbf{2 3} \leq \mathbf{h} \\
\mathbf{3 5}\end{array}$ & $\begin{array}{c}\mathbf{3 5} \leq \mathbf{h} \\
\leq \mathbf{5 0}\end{array}$ & $\begin{array}{c}\text { THD } \\
(\mathbf{\%})\end{array}$ \\
\hline$<20^{\mathrm{c}}$ & 4,0 & 2,0 & 1,5 & 0,6 & 0,3 & 5,0 \\
\hline $20<50$ & 7,0 & 3,5 & 2,5 & 1,0 & 0,5 & 8,0 \\
\hline $50<100$ & 10,0 & 4,5 & 4,0 & 1,5 & 0,7 & 12,0 \\
\hline $100<1000$ & 12,0 & 5,5 & 5,0 & 2,0 & 1,0 & 15,0 \\
\hline$>1000$ & 15,0 & 7,0 & 6,0 & 2,5 & 1,4 & 20,0 \\
\hline
\end{tabular}

\section{Damped Filter}

Damped Filter digunakan untuk memberikan pergantian selama rentang frekuensi yang luas. Ketika arus harmonik mencapai nilai-nilai yang besar, damped filter digunakan dalam hubungannya dengan Tuned Filter yang mengurangi frekuensi rendah, sedangkan damped filter mengurangi harmonik pada frekuensi yang tinggi [3]. Pada umumnya digunakan topologi damped filter yang ditunjukkan pada Gambar 2.
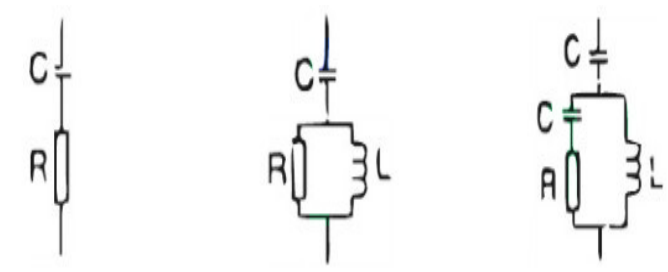

Gambar 2. Damped Filter: first order, second order, dan third order [3]

I Kadek Arya Wiguna: Analisis Penggunaan Filter Damped...

Parameter damped filter yang dihitung dalam simulasi adalah sebagai berikut [3]:

- Daya reaktif untuk memperbaiki faktor daya dapat dihitung dengan persamaan berikut:

$$
Q_{V A R}=\sqrt{\left(\frac{P_{1}}{p f_{0}}\right)^{2}-P_{1}^{2}}-\sqrt{\left(\frac{P_{1}}{p f_{1}}\right)^{2}-P_{1}^{2}}
$$

Dimana P1 adalah daya aktif masing-masing SDP, $\mathrm{pf}_{0}$ dan $\mathrm{pf}_{1}$ adalah faktor daya untuk masing-masing beban.

- Nilai reaktansi dari kapasitor dapat dihitung menggunakan persamaan berikut:

$$
X_{C}=\frac{k V^{2} \text { rated }}{M_{V A R \text { rated }}}
$$

Dimana $\mathrm{kv}_{\text {rated }}$ adalah tegangan yang terukur pada tiap SDP, dan MVAR $_{\text {rated }}$ adalah daya reaktif pada tiap SDP.

- Besar nilai kapasitor dapat dihitung menggunakan persamaan berikut:

$$
C=\frac{1}{2 \pi f X_{C}}
$$

Dengan : $\mathrm{f}=$ frekuensi fundamental $50 \mathrm{~Hz}$

- Besar impedansi reaktor filter dapat dihitung menggunakan persamaan berikut:

$$
X_{L}=\frac{X_{C}}{n^{2}}
$$

Dengan $: \mathrm{n}=$ orde harmonik tegangan yang difilter (disetel sedikit di bawah ordenya). Pada simulasi ini, orde yang akan difilter adalah orde 5, sehingga nilai $\mathrm{n}$ akan sedikit di bawahnya yaitu 4,9. Hal ini dilakukan sebagai toleransi komponen filter untuk mencegah adanya resonansi yang terjadi dalam sistem pada frekuensi yang mengganggu [8].

- Besar induktansi induktor dapat dihitung dengan menggunakan persamaan berikut:

$$
L=\frac{X_{L}}{2 \pi f}
$$

Dengan : $\pi=3,14$

- Nilai karakteristik reaktansi dapat dihitung dengan persamaan berikut:

$$
X_{n}=\sqrt{\frac{L}{C}}
$$

- Besarnya resistansi filter dapat dihitung dengan persamaan berikut:

$$
R=X_{n} Q
$$

p-ISSN:1693 - 2951; e-ISSN: 2503-2372 
Pada perancangan filter kali ini, nilai Q yang digunakan yaitu 5. Nilai $Q$ adalah ukuran ketajaman penyetelan filter dalam mereduksi harmonik.

\section{METODE PENELITIAN}

Penelitian dilaksanakan di Rumah Sakit Umum Daerah (RSUD) Klungkung mulai tanggal 19 Januari 2016 sampai Maret 2016. Pengumpulan data dilakukan dengan pengukuran langsung ke lokasi terkait dan wawancara dengan narasumber yang bertanggung jawab. Adapun data yang diperoleh yaitu data pengukuran THD, data single line diagram, data jumlah beban yang terpasang, dan data spesifikasi trafo di RSUD Klungkung.

Data yang diperoleh dalam penelitian ini dianalisis dengan prosedur yaitu pertama mengelompokkan beban non linier pada tiap-tiap SDP. Kemudian dilakukan perhitungan arus hubung singkat, arus beban, dan rasio hubung singkat untuk menentukan batas maksimum $\mathrm{THD}_{\mathrm{I}}$ yang diperbolehkan dan disesuaikan dengan standar IEEE 519-2014. Langkah selanjutnya adalah membuat pemodelan sistem kelistrikan di RSUD Klungkung. Simulasi dilakukan dengan bantuan perangkat lunak ETAP, dimana simulasi dilakukan dalam dua kondisi yaitu simulasi sistem tanpa pemasangan damped filter, dan simulasi sistem dengan pemasangan damped filter. Kemudian, kedua hasil simulasi akan dibandingkan untuk mengetahui kemampuan damped filter dalam menurunkan atau mereduksi THD di RSUD Klungkung. Alur analisis pada penelitian ini dapat dilihat pada Gambar 3.

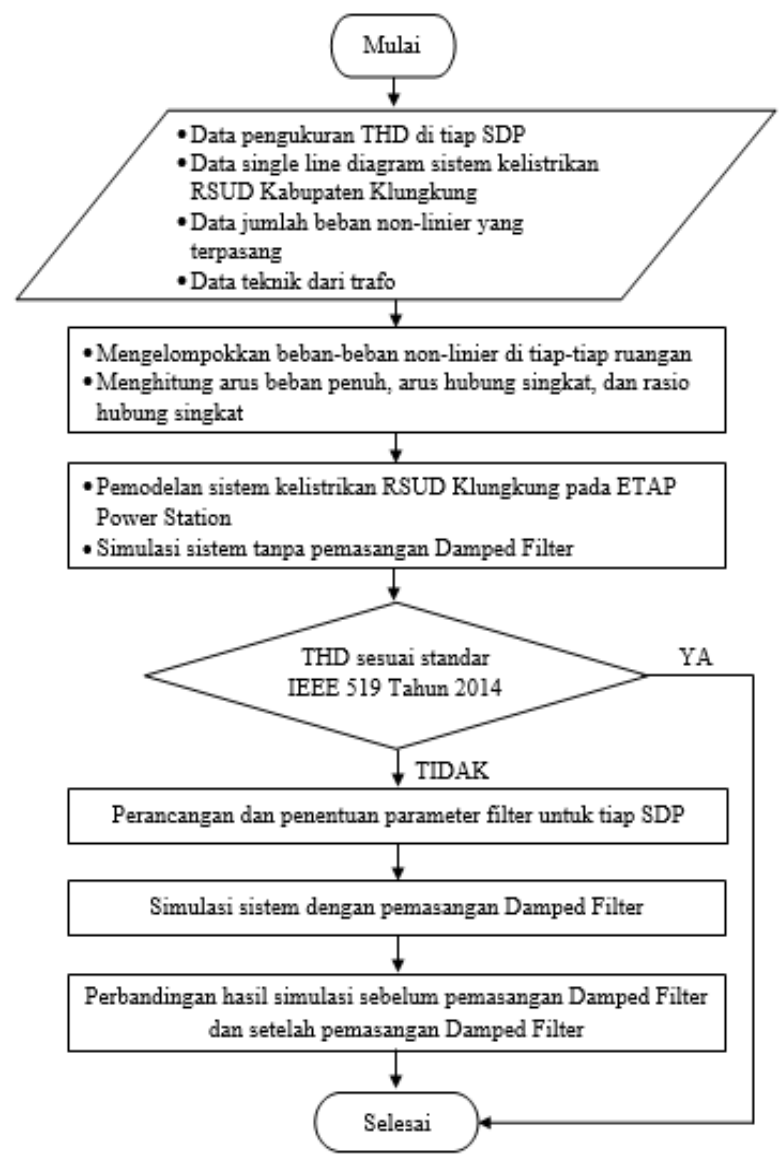

Gambar 3. Alur Analisis

\section{HASIL SIMULASI DAN ANALISIS}

\section{A. Hasil Pengukuran}

Sistem kelistrikan di RSUD Klungkung disuplai dari jaringan PLN melalui penyulang Klungkung. Transformator yang terpasang berkapasitas $200 \mathrm{kVA}$, dengan tegangan primer $20 \mathrm{kV}$ dan tegangan sekunder $400 \mathrm{~V}$ serta impedansi sebesar 4\%. Single line diagram dari sistem kelistrikan RSUD Kabupaten Klungkung dapat dilihat pada Gambar 4 dimana pengukuran dilakukan pada SDP yang terhubung ke transformator 1 saja. 


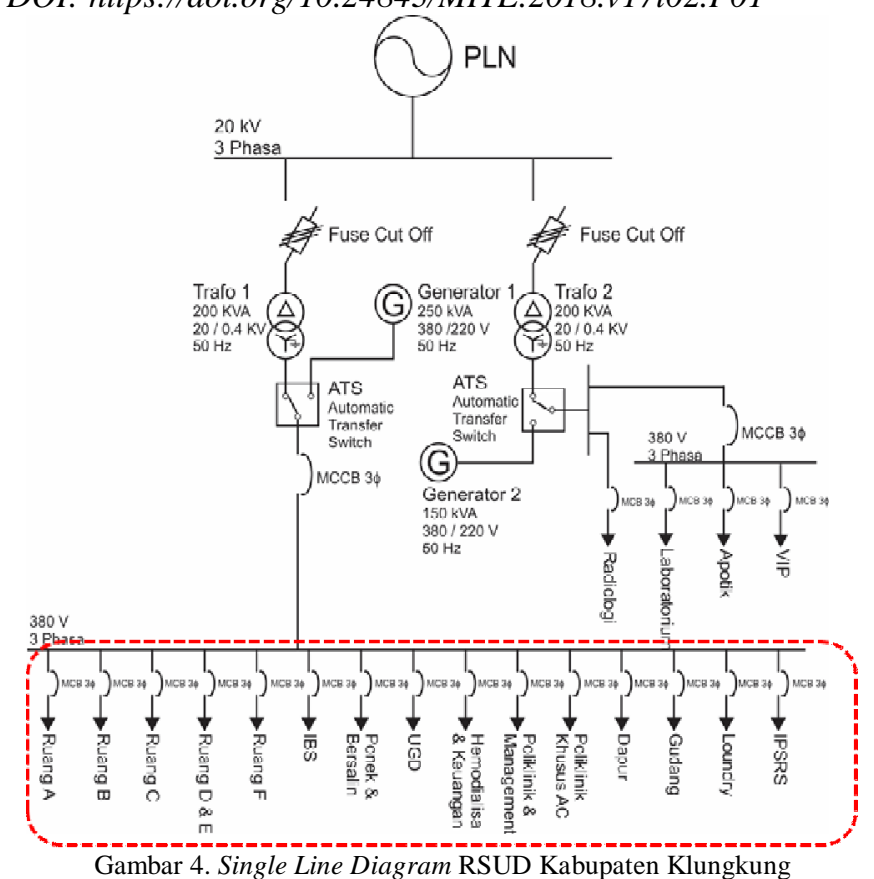

Gambar 4. Single Line Diagram RSUD Kabupaten Klungkung

Pengukuran dilakukan langsung di tiap SDP pada saat beban puncak menggunakan alat ukur Clamp On Power HiTester Hioki 3286-20. Berdasarkan hasil pengukuran yang dilakukan, diperoleh data untuk tiap-tiap SDP seperti ditunjukkan pada Tabel III.

TABEL III

HASIL PENGUKURAN DI TIAP-TIAP SDP

\begin{tabular}{|c|l|c|c|c|}
\hline No & \multicolumn{1}{|c|}{ SDP } & $\begin{array}{c}\text { Daya Aktif } \\
(\mathbf{k W})\end{array}$ & $\begin{array}{c}\text { Cos } \\
\boldsymbol{\varphi}\end{array}$ & $\begin{array}{c}\text { Daya Semu } \\
(\mathbf{k V A})\end{array}$ \\
\hline 1 & Ruang A & 2,214 & 0,93 & 2,381 \\
\hline 2 & Ruang B & 4,088 & 0,92 & 4,443 \\
\hline 3 & Ruang C & 5,483 & 0,94 & 5,833 \\
\hline 4 & Ruang D \& E & 5,050 & 0,95 & 5,316 \\
\hline 5 & Ruang F & 2,171 & 0,90 & 2,412 \\
\hline 6 & IBS & 11,37 & 0,95 & 11,968 \\
\hline 7 & Ponek \& Bersalin & 6,069 & 0,98 & 6,192 \\
\hline 8 & UGD & 13,889 & 0,75 & 18,519 \\
\hline 9 & Hmodialisa \& Keuangan & 18,735 & 0,95 & 19,721 \\
\hline 10 & Poliklinik \& Management & 6,285 & 0,88 & 7,142 \\
\hline 11 & Poliklinik Khusus AC & 29,305 & 0,96 & 30,526 \\
\hline 12 & Dapur & 3,217 & 0,74 & 4,347 \\
\hline 13 & Gudang & 1,639 & 0,79 & 2,075 \\
\hline 14 & Loundry & 2,281 & 0,84 & 2,715 \\
\hline 15 & IPSRS & 0,556 & 0,97 & 0,573 \\
\hline
\end{tabular}

\section{B. Batas maksimum $T H D_{I}$ dan $T H D_{V}$ di RSUD Klungkung}

Menurut IEEE Standard 519 - 2014, untuk menentukan batas maksimum $\mathrm{THD}_{\mathrm{I}}$ pada utiliti, maka harus diketahui terlebih dahulu rasio hubung singkat (short-circuit ratio). Untuk menentukan nilai $\mathrm{SC}_{\text {ratio}}$, nilai arus hubung singkat $\left(\mathrm{I}_{\mathrm{SC}}\right)$ dan nilai arus beban penuh $\left(\mathrm{I}_{\mathrm{L}}\right)$ harus diketahui terlebih dahulu. Persamaan (1), (2), dan (3) digunakan untuk menghitung nilai SCratio, ISC, dan IL. Hasil perhitungan nilai SCratio untuk masing-masing SDP dapat dilihat pada Tabel IV.

I Kadek Arya Wiguna: Analisis Penggunaan Filter Damped...
TABEL IV

$\mathrm{I}_{\mathrm{SC}}, \mathrm{I}_{\mathrm{L}}, \mathrm{DAN} \mathrm{SC}_{\mathrm{RATIO}}$ MASING-MASING SDP

\begin{tabular}{|l|l|c|c|c|}
\hline No & \multicolumn{1}{|c|}{ SDP } & $\mathbf{I}_{\mathbf{S C}}(\mathbf{A})$ & $\mathbf{I}_{\mathbf{L}}(\mathbf{A})$ & $\mathbf{S C}_{\text {Ratio }}$ \\
\hline 1 & Ruang A & 152,082 & 6,083 & 25 \\
\hline 2 & Ruang B & 285,058 & 11,402 & 25 \\
\hline 3 & Ruang C & 374,231 & 14,969 & 25 \\
\hline 4 & Ruang D \& E & 342,574 & 13,703 & 25 \\
\hline 5 & Ruang F & 155,475 & 6,219 & 25 \\
\hline 6 & IBS & 771,225 & 30,849 & 25 \\
\hline 7 & Ponek \& Bersalin & 397,284 & 15,891 & 25 \\
\hline 8 & UGD & 1188,051 & 47,522 & 25 \\
\hline 9 & Hemodialisa \& Keuangan & 1276,490 & 51,060 & 25 \\
\hline 10 & Poliklinik \& Management & 460,221 & 18,409 & 25 \\
\hline 11 & Poliklinik Khusus AC & 1958,304 & 78,332 & 25 \\
\hline 12 & Dapur & 278,931 & 11,157 & 25 \\
\hline 13 & Gudang & 134,330 & 5,373 & 25 \\
\hline 14 & Loundry & 172,668 & 6,907 & 25 \\
\hline 15 & IPSRS & 36,642 & 1,466 & 25 \\
\hline
\end{tabular}

Dari hasil perhitungan SCratio pada tiap SDP yang terpasang di RSUD Klungkung, batas maksimum THD Arus adalah sebesar $8 \%$.

Sedangkan untuk $\mathrm{THD}_{\mathrm{V}}$ berdasarkan IEEE standard 5192014 berisikan tentang nilai-nilai yang dijadikan sebagai batas maksimum distorsi harmonisa tegangan yang direkomendasikan terhadap sistem, maka batas maksimum $\mathrm{THD}_{\mathrm{v}}$ yang diperbolehkan di RSUD Kabupaten Klungkung menurut IEEE standard 519 - 2014 adalah $8.0 \%$.

\section{Pemodelan dan Simulasi THD}

Pemodelan dan simulasi THD dilakukan dengan bantuan sofware ETAP dengan menggunakan pendekatan pada kondisi sistem yang sebenarnya. Pada penelitian ini, simulasi THD hanya pada SDP yang terhubung ke trafo 1. Pemodelan dan hasil running sistem dapat dilihat pada Lampiran Gambar 5.

Tampilan hasil running spektrum harmonik dan bentuk gelombang dari simulasi yang dilakukan pada software ETAP dapat dilihat pada Gambar 6 dan Gambar 7 berikut ini:

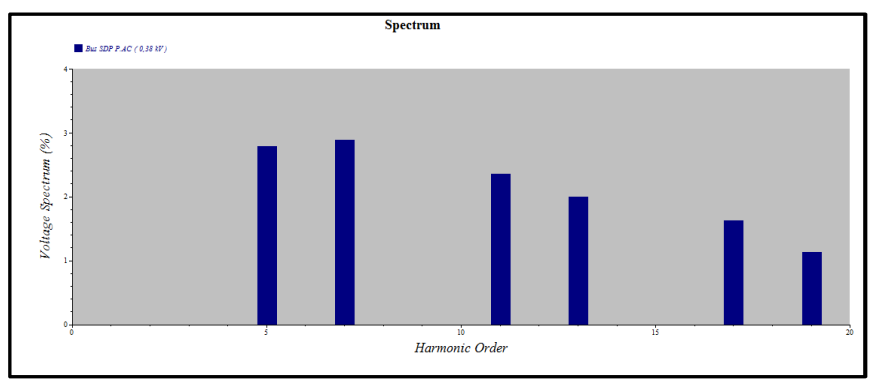

Gambar 6. Spektrum Harmonik tegangan SDP P.AC sebelum penambahan damped filter

p-ISSN:1693 - 2951; e-ISSN: 2503-2372 
Majalah Ilmiah Teknologi Elektro, Vol. 17, No. 2 Mei - Agustus 2018

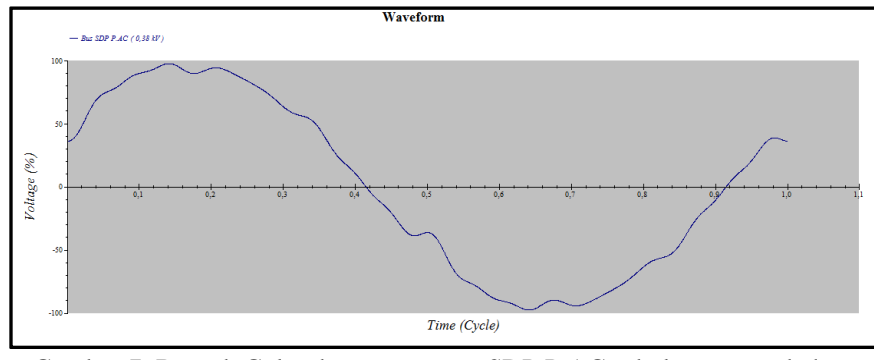

Gambar 7. Bentuk Gelombang tegangan SDP P.AC sebelum penambahan damped filter

Gambar 6 menunjukkan kandungan harmonisa arus pada setiap orde dimana pada simulasi, spektrum yang ditampilkan dimulai dari orde 5 hingga orde 19. Gambar 7 menunjukkan bentuk gelombang harmonisa arus pada bus SDP P.AC, dimana kandungan harmonisa pada sistem distribusi akan menyebabkan bentuk gelombang sinusoidal menjadi cacat atau terdistorsi.

\section{Analisis $T H D_{I}$ dan $T H D_{V}$}

Berikut ini adalah perbandingan nilai $\mathrm{THD}_{\mathrm{I}}$ hasil simulasi dengan Standar IEEE 519 tahun 2014 pada masing-masing SDP yang terpasang di RSUD Kabupaten Klungkung.

TABEL V

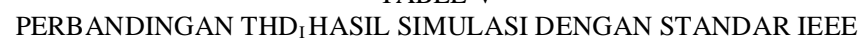
519 TAHUN 2014

\begin{tabular}{|l|c|c|c|}
\hline \multicolumn{1}{|c|}{ SDP } & $\begin{array}{c}\text { THD Hasil } \\
\text { Simulasi (\%) })\end{array}$ & $\begin{array}{c}\text { Standar } \\
\text { IEEE 519- } \\
\mathbf{2 0 1 4}(\%)\end{array}$ & Ket \\
\hline Ruang A & 14,70 & 8 & Melewati standar \\
\hline Ruang B & 8,11 & 8 & Melewati standar \\
\hline Ruang C & 14,68 & 8 & Melewati standar \\
\hline Ruang D\&E & 11,05 & 8 & Melewati standar \\
\hline Ruang F & 16,03 & 8 & Melewati standar \\
\hline UGD & 3,93 & 8 & Sesuai standar \\
\hline Bedah Sentral (IBS) & 10,11 & 8 & Melewati standar \\
\hline Ponek & 16,99 & 8 & Melewati standar \\
\hline Hemodialisa (HD) & 19,08 & 8 & Melewati standar \\
\hline Poliklinik & 9,21 & 8 & Melewati standar \\
\hline Poliklinik Khusus AC & 45,73 & 8 & Melewati standar \\
\hline Dapur & 14,54 & 8 & Melewati standar \\
\hline Gudang & 32,25 & 8 & Melewati standar \\
\hline Laundry & 26,50 & 8 & Melewati standar \\
\hline IPSRS & 12,74 & 8 & Melewati standar \\
\hline
\end{tabular}

Dari Tabel V di atas dapat dilihat bahwa THDI pada tiap SDP yang terpasang di RSUD Klungkung telah melewati standar atau lebih dari $8 \%$, kecuali pada SDP UGD yang masih sesuai standar.

TABEL VI

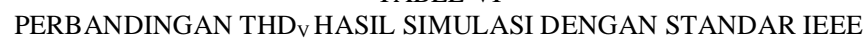
519 TAHUN 2014

\begin{tabular}{|l|c|c|c|}
\hline \multicolumn{1}{|c|}{ SDP } & $\begin{array}{c}\text { THDV Hasil } \\
\text { Simulasi (\%) }\end{array}$ & $\begin{array}{c}\text { Standar } \\
\text { IEEE 519- } \\
\mathbf{2 0 1 4}(\boldsymbol{\%})\end{array}$ & Ket \\
\hline Ruang A & 5,26 & 8 & Sesuai standar \\
\hline Ruang B & 5,25 & 8 & Sesuai standar \\
\hline Ruang C & 5,30 & 8 & Sesuai standar \\
\hline
\end{tabular}

\begin{tabular}{|l|l|l|l|}
\hline Ruang D\&E & 5,26 & 8 & Sesuai standar \\
\hline Ruang F & 5,25 & 8 & Sesuai standar \\
\hline UGD & 5,27 & 8 & Sesuai standar \\
\hline Bedah Sentral (IBS) & 5,29 & 8 & Sesuai standar \\
\hline Ponek & 5,28 & 8 & Sesuai standar \\
\hline Hemodialisa (HD) & 5,44 & 8 & Sesuai standar \\
\hline Poliklinik & 5,26 & 8 & Sesuai standar \\
\hline Poliklinik Khusus AC & 5,66 & 8 & Sesuai standar \\
\hline Dapur & 5,27 & 8 & Sesuai standar \\
\hline Gudang & 5,26 & 8 & Sesuai standar \\
\hline Laundry & 5,25 & 8 & Sesuai standar \\
\hline IPSRS & 5,24 & 8 & Sesuai standar \\
\hline
\end{tabular}

Dari Tabel VI di atas dapat dilihat nilai $\mathrm{THD}_{\mathrm{V}}$ hasil simulasi untuk masing-masing SDP yang terpasang telah sesuai standar atau tidak lebih dari $8 \%$.

\section{E. Setting Damped Filter}

Persamaan (4) hingga (10) digunakan untuk menentukan parameter filter sesuai dengan data pengukuran awal yang telah dilakukan. Nilai-nilai yang dihitung akan digunakan sebagai parameter nilai dalam perancangan filter pada simulasi. Simulasi dilakukan dengan bantuan software ETAP dan model penempatan filter di SDP P.AC, dimana persentase $\mathrm{THD}_{\text {I }}$ paling besar terdapat di SDP P.AC sebesar $45,73 \%$. Jenis filter yang digunakan adalah tipe High Pass Damped Filter

Hasil perhitungan parameter filter untuk SDP P.AC dapat dilihat pada Tabel VII.

TABEL VII

PARAMETER SPESIFIKASI FILTER PADA SDP P.AC

\begin{tabular}{|c|c|}
\hline Spesifikasi & Nilai \\
\hline $\mathrm{L}$ & $0,0024 \mathrm{H}$ \\
\hline $\mathrm{XL}$ & 0,705 \\
\hline $\mathrm{C}$ & $18,8 \times 10^{-5} \mathrm{~F}$ \\
\hline $\mathrm{XC}$ & 16,93 \\
\hline $\mathrm{R}$ & $17,25 \Omega$ \\
\hline QVAR & $8,529 \mathrm{kVAR}$ \\
\hline Rating Tegangan & 380 Volt \\
\hline Q Factor & 5 \\
\hline
\end{tabular}

Input parameter spesifikasi filter pada simulasi ETAP dapat dilihat pada Gambar 8.

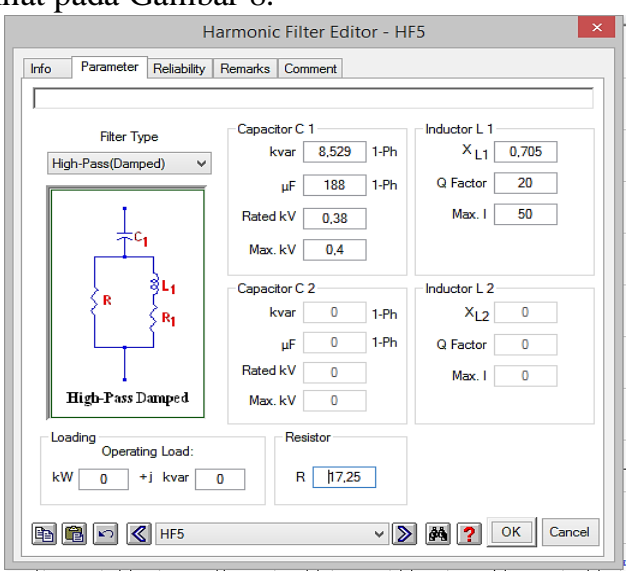


PERBANDINGAN THD I HASIL RUNNING TANPA FILTER DAN SETELAH DI PASANG FILTER

\section{F. Simulasi Sistem Setelah penambahan Filter}

Dengan penempatan filter pada SDP PAC, spektrum harmonik dan bentuk gelombang tegangannya mengalami perubahan, dimana nilai harmonisa dapat diturunkan oleh filter yang terpasang. Berikut ini adalah tampilan spektrum harmonik dan bentuk gelombang hasil running setelah penambahan filter.

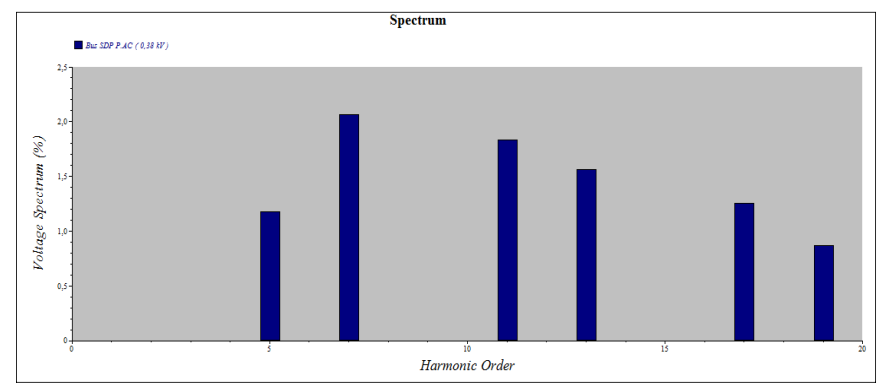

Gambar 9. Spektrum harmonik SDP P.AC setelah penambahan filter

Penambahan filter dapat mereduksi harmonik pada orde 5 , dimana pada penentuan parameter filter ditetapkan kandungan harmonik yang akan direduksi adalah pada orde 5. Penurunan kandungan harmonik ini akan berpengaruh pada tampilan gelombang tegangan seperti pada Gambar 10 berikut ini.

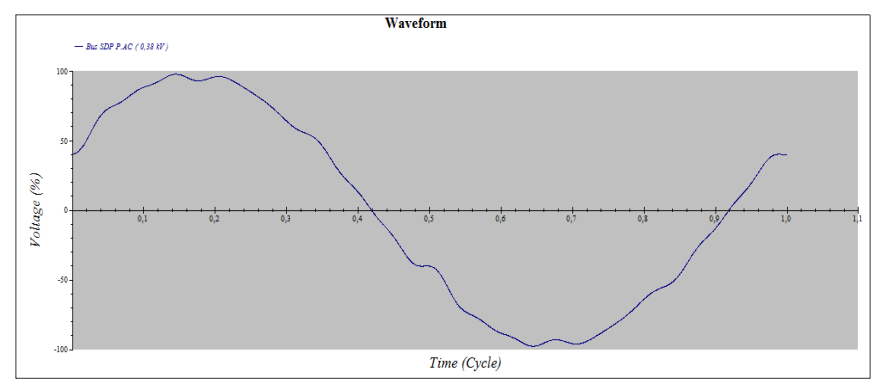

Gambar 10. Bentuk gelombang setelah penambahan filter

Dengan menurunnya nilai THD, bentuk gelombang mengalami perbaikan dengan cacat gelombang yang lebih sedikit dibandingkan dengan bentuk gelombang sebelum penambahan High Pass Damped Filter.

\section{G. Analisis $T H D_{I}$ dan $T H D_{V}$ di RSUD Klungkung Setelah di Pasang High Pass Damped Filter}

Berdasarkan simulasi yang dilakukan, terdapat perbedaan nilai THDI sebelum dan setelah penambahan High Pass Damped Filter. Hasil analisis $\mathrm{THD}_{\mathrm{I}}$ sebelum dan setelah penambahan High Pass Damped Filter serta perbandingannya dengan Standar IEEE 519 tahun 2014 dapat dilihat pada Tabel VIII berikut ini

TABEL VIII

I Kadek Arya Wiguna: Analisis Penggunaan Filter Damped...

\begin{tabular}{|l|c|c|c|c|}
\hline \multicolumn{1}{|c|}{ SDP } & $\begin{array}{c}\text { THD } \\
\text { tanpa } \\
\text { filter (\%) }\end{array}$ & $\begin{array}{c}\text { THD } \\
\text { dengan } \\
\text { filter (\%) }\end{array}$ & $\begin{array}{c}\text { Selisih } \\
(\%)\end{array}$ & $\begin{array}{c}\text { Standar } \\
\text { IEEE 519- } \\
\mathbf{2 0 1 4}(\%)\end{array}$ \\
\hline Ruang A & 14,70 & 8,90 & 5,8 & 8 \\
\hline Ruang B & 8,11 & 3,96 & 4,15 & 8 \\
\hline Ruang C & 14,68 & 8,97 & 5,71 & 8 \\
\hline Ruang D\&E & 11,05 & 6,02 & 5,03 & 8 \\
\hline Ruang F & 16,03 & 8,32 & 7,71 & 8 \\
\hline UGD & 3,93 & 3,93 & 0 & 8 \\
\hline Bedah Sentral (IBS) & 10,11 & 5,47 & 4,64 & 8 \\
\hline Ponek & 16,99 & 11,49 & 5,5 & 8 \\
\hline Hemodialisa (HD) & 19,08 & 13,68 & 5,4 & 8 \\
\hline Poliklinik & 9,21 & 4,79 & 4,42 & 8 \\
\hline Poliklinik Khusus AC & 45,73 & 35,10 & 10,63 & 8 \\
\hline Dapur & 14,54 & 10,24 & 4,3 & 8 \\
\hline Gudang & 32,25 & 23,06 & 9,19 & 8 \\
\hline Laundry & 26,50 & 16,91 & 9,59 & 8 \\
\hline IPSRS & 12,74 & 10,74 & 2 & 8 \\
\hline
\end{tabular}

Setelah penambahan filter, kandungan $\mathrm{THD}_{\mathrm{I}}$ pada beberapa SDP dapat direduksi dan telah memenuhi Standar IEEE 519-2014, namun ada beberapa SDP dengan kandungan $\mathrm{THD}_{\text {I }}$ yang masih melewati standar.

Hasil analisis THDv sebelum dan setelah penggunaan High Pass Damped Filter serta perbandingannya dengan Standar IEEE 519 tahun 2014 pada masing-masing SDP dapat dilihat pada Tabel IX.

TABEL IX

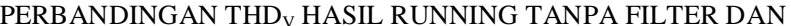
SETELAH DI PASANG FILTER

\begin{tabular}{|l|c|c|c|c|}
\hline \multicolumn{1}{|c|}{ SDP } & $\begin{array}{c}\text { THDV } \\
\text { tanpa } \\
\text { filter (\%) }\end{array}$ & $\begin{array}{c}\text { THD } \\
\text { dengan } \\
\text { filter (\%) }\end{array}$ & $\begin{array}{c}\text { Selisih } \\
(\%)\end{array}$ & $\begin{array}{c}\text { Standar } \\
\text { IEEE 519- } \\
\mathbf{2 0 1 4}(\%)\end{array}$ \\
\hline Ruang A & 5,26 & 3,53 & 1,73 & 8 \\
\hline Ruang B & 5,25 & 3,52 & 1,73 & 8 \\
\hline Ruang C & 5,30 & 3,55 & 1,75 & 8 \\
\hline Ruang D\&E & 5,26 & 3,53 & 1,73 & 8 \\
\hline Ruang F & 5,25 & 3,52 & 1,73 & 8 \\
\hline UGD & 5,27 & 3,55 & 1,72 & 8 \\
\hline Bedah Sentral (IBS) & 5,29 & 3,54 & 1,75 & 8 \\
\hline Ponek & 5,28 & 3,54 & 1,74 & 8 \\
\hline Hemodialisa (HD) & 5,44 & 3,64 & 1,8 & 8 \\
\hline Poliklinik & 5,26 & 3,53 & 1,73 & 8 \\
\hline Poliklinik Khusus AC & 5,57 & 3,84 & 1,73 & 8 \\
\hline Dapur & 5,27 & 3,54 & 1,73 & 8 \\
\hline Gudang & 5,26 & 3,53 & 1,73 & 8 \\
\hline Laundry & 5,25 & 3,53 & 1,72 & 8 \\
\hline IPSRS & 5,24 & 3,52 & 1,72 & 8 \\
\hline
\end{tabular}

Dari Tabel IX dapat dilihat bahwa nilai $\mathrm{THD}_{\mathrm{V}}$ pada masing-masing SDP setelah pemasangan High Pass Damped Filter mengalami penurunan dan dapat memenuhi standar IEEE 519 tahun 2014. Penurunan terbesar terdapat pada SDP HD sebesar $1,8 \%$, dan penurunan terrendah terdapat pada SDP UGD, SDP Laundry, dan SDP IPSRS sebesar 1,72\%.

\section{KESIMPULAN}

p-ISSN:1693 - 2951; e-ISSN: 2503-2372 
Dari simulasi yang telah dilakukan diketahui bahwa High Pass Damped Filter mampu mereduksi $\mathrm{THD}_{\mathrm{V}}$ dan $\mathrm{THD}_{\mathrm{I}}$. Nilai $\mathrm{THD}_{\mathrm{V}}$ dengan penurunan terbesar terdapat pada SDP HD sebesar 1,8 \% dan penurunan terendah pada SDP UGD, Laundry, dan IPSRS sebesar $1,72 \%$. Nilai THD $_{\text {I }}$ juga dapat direduksi dengan penurunan terbesar terdapat pada SDP P.AC sebesar 10,63\%, dan penurunan terendah terdapat pada SDP IPSRS sebesar $2 \%$.

Kandungan $\mathrm{THD}_{\mathrm{V}}$ pada masing-masing SDP setelah pemasangan filter telah sesuai dengan standar IEEE 519 tahun 2014 seperti pada Tabel IX. Sedangkan untuk THD $_{\text {I }}$ terdapat beberapa SDP dengan kandungan $\mathrm{THD}_{\mathrm{I}}$ yang telah sesuai dengan standar, namun terdapat pula beberapa SDP dengan kandungan $\mathrm{THD}_{\mathrm{I}}$ yang melewati standar IEEE 519 tahun 2014 seperti pada Tabel VIII.

\section{REFERENSI}

[1] Harlow, J.H. 2004. Electric Power Engineering. United States of America : CRC Press.

[2] Dugan, R.C., McGranaghan, M.F., Santoso, S., Beaty, H.W. 2004. Electrical Power System Quality-Second Edition. The McGraw-Hill.

[3] Ahmed, K., Jovcic, D., 2015. High Voltage Direct Current Transmission. School of Engineering University of Aberdeen UK : Wiley.

\section{LAMPIRAN}

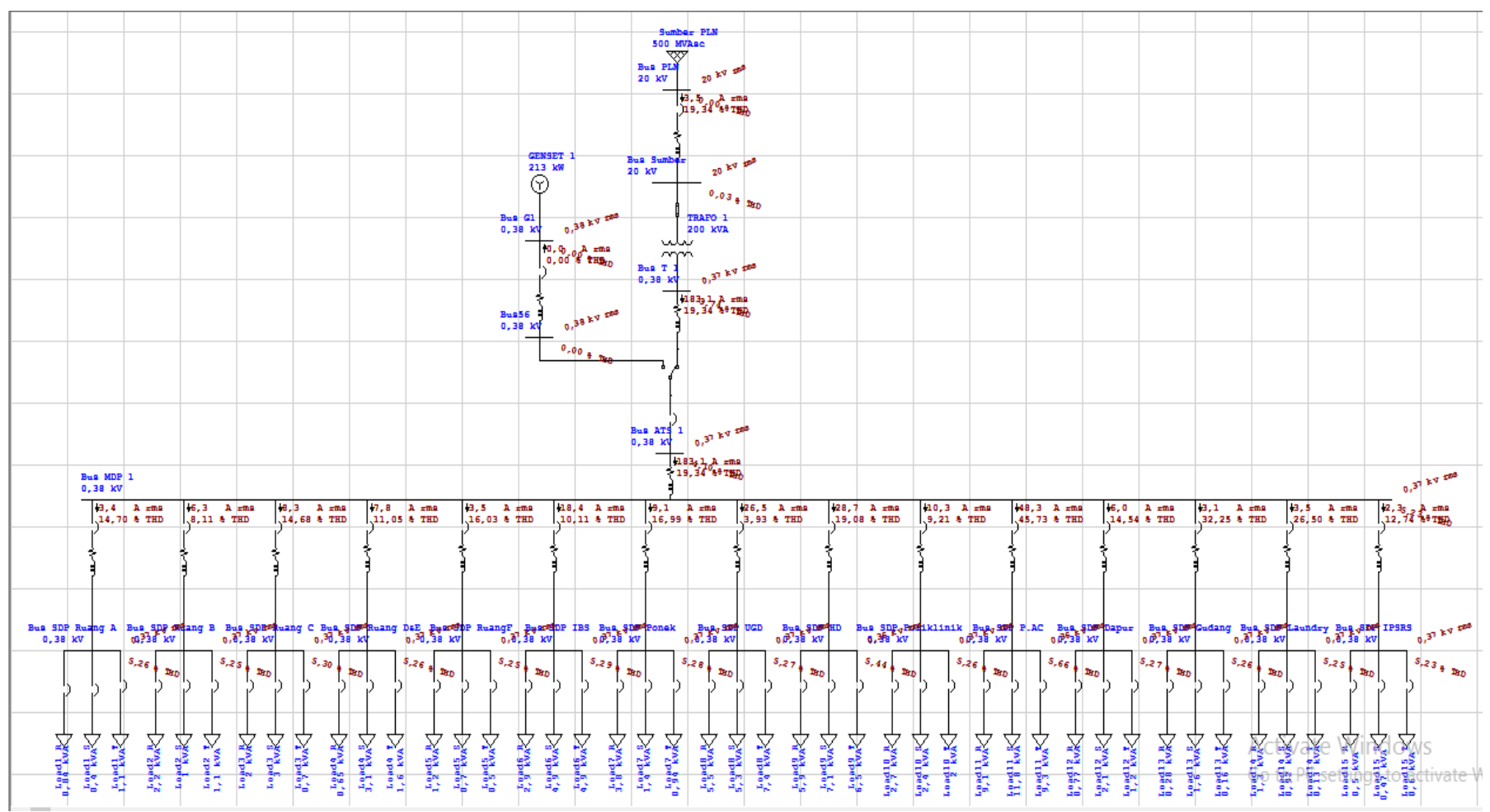

Gambar 5. Hasil running analisis THDI dan THDv di RSUD Klungkung

[4] Margareta, I.W., 2014. "Perancangan High Pass Damped Filter Pada Sistem Distribusi Standar IEEE 9 Bus Dengan Menggunakan Software ETAP Power Station 7.0". Surakarta : Universitas Muhamadiyah Surakarta.

[5] Rinas, I.W., 2011. Analisis Perbandingan Penggunaan Filter Pasif Dan Filter Aktif Untuk Menanggulangi THD Pada Sistem Kelistrikan Di Ruang Puskom Jurusan Teknik Elektro Fakultas Teknik Universitas Udayana. Teknologi Elektro, Vol. 10 (Januari - Juni) : 20 - 26.

[6] Rinas, I.W., Sweden, I.N. 2009. Studi Analisa Penanggulangan THD dengan Filter Pasif Pada Sistem Kelistrikan Di RSUP Sanglah. Teknologi Elektro, Vol. 8 No.2 (Juli - Desember) : 7 - 13.

[7] IEEE Recommended Practices and Requirements for Harmonic Control in Electric Power Systems. IEEE Standard 519-2014.

[8] Arrilaga, J., Smith, B.C., Watson, N.R., Wood, A.R., 1997. Power System Harmonic Analysis. United States of America : John Wiley \& Sons.

[9] Gonen, T. 2008. Electric Power Distribution System Engineering, Second Edition. United States of America : CRC Press.

[10] Das, J.C., 2002. Power System Analysis, Short-Circuit Load Flow and Harmonics. United States of America : Marcel Dekker. 